\title{
AUTUMN FAT DEPOSITION AND GROSS BODY COMPOSITION IN THREE SPECIES OF MYOTIS
}

\author{
WILLIAM G. EWING, EUGENE H. STUDIER \\ and MICHAEL J. O'FARRELL \\ Institute of Scientific Research, New Mexico Highlands University, Las Vegas, New Mexico
}

(Received 3 March 1970)

\begin{abstract}
Mid-August to mid-September fat indices for female Myotis lucifugus were $0.58-0.69 \mathrm{~g}$ fat $/ \mathrm{g}$ lean dry wt. with constant gross body composition.

2. During the same time span, fat indices of female $M$. yumanensis showed a gradual significant increase from 0.30 to 0.87 with a concurrent significant increase in percent non-fat and percent water.

3. In mid-September, fat indices of $M$. thysanodes increased significantly from 0.09 to 0.73 , while gross body composition was unchanged.

4. $M$. thysanodes body fat had a caloric content of $9.418 \pm 0.016 \mathrm{kcal} / \mathrm{g}$.

5. Fatty acid analysis revealed $72-81$ per cent unsaturation with oleic acid being the most abundant.

6. For each species, females contained more body fat than males, and adults were fatter than young of the year.
\end{abstract}

\section{INTRODUCTION}

LATE summer fat deposition, which is recognized as a prerequisite for migration in birds (Odum, 1965; King \& Farner, 1965; Hicks, 1967), has been reported for Nycticieus humeralis (Baker et al., 1968), Tadarida brasiliensis (Herreid, 1963), Eptesicus fuscus (Weber \& Findley, 1970), and several species of bats in Poland (Krzanowski, 1961). The present study was conducted to determine the extent of fat deposition and concurrent changes in gross body composition in Myotis lucifugus occultus ( $=M$. occultus, Findley \& Jones, 1967), $M$. yumanensis, and $M$. thysanodes during the 4-5 weeks prior to their mid-September departure from a common maternity roost.

\section{MATERIALS AND METHODS}

Several bats of each of the above species of Myotis were removed at random in the early morning from their maternity roost in the attic of Montezuma Seminary, Montezuma, San Miguel Co., New Mexico. Collection days were spaced in $1 \frac{1}{2}$ to 2 week intervals from mid-August to late-September, 1969. On 25 September only $M$. thysanodes remained in the roost. Sample sizes were kept small to prevent a serious disruption of the colony.

Approximately $3 \mathrm{hr}$ after collection, the bats were killed, weighed, and dried to constant weight under reduced pressure at $40^{\circ} \mathrm{C}$. Dried bats were reweighed and ground in a mortar, and fats were extracted with petroleum ether (b.p. $90-110^{\circ} \mathrm{C}$ ). All fat-free residues were air dried to constant weight and the residues from adults were ashed at $620^{\circ} \mathrm{C}$ for $8 \mathrm{hr}$. Fats 
extracted from selected adults were air dried and analyzed for fatty acid and lipid phosphorous content by gas-liquid and thin layer chromatography (Christopherson \& Glass, 1969). Lipids from sub-cutaneous peritoneal adipose tissue, collected from six $M$. thysanodes on 18 September were similarly extracted for determination of caloric content by bomb calorimetry using a Series 1300 Parr oxygen bomb calorimeter.

Fat index (g fat/g lean dry wt.), water index ( $g$ water/g lean dry wt.), percent nonfat organic, percent ash and percent water were calculated for each bat. Inter- and intraspecific comparisons of these parameters were made using a simple $t$-test analysis with the 0.05 level of significance indicating rejection of the null hypothesis of no difference.

\section{RESULTS}

Mean fat indices (Fig. 1-A, Table 1) for $M$. lucifugus and $M$. yumanensis on the same days were not significantly different, while the $M$. thysanodes fat index for 1 September was significantly lower than that of the other two species $(P<0.02)$. None of the three final fat indices differed significantly. Mean water indices (Fig. 1-B, Table 1) on corresponding days were not significantly different.

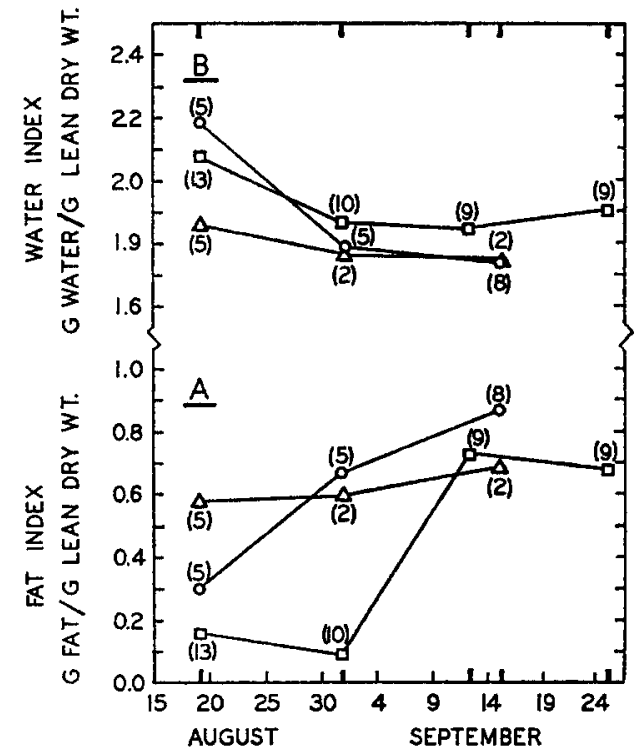

FIG. 1. Mean fat indices (A) and water indices (B) of M. lucifugus ( $\triangle)$, M. yumanensis $(\odot)$ and $M$. thysanodes $(\square)$ in autumn. Sample size is indicated in parentheses.

The fat index of $M$. lucifugus showed no significant intraspecific change throughout the study period, while the fat indices of $M$. yumanensis and $M$. thysanodes increased significantly $(P<0 \cdot 05$ and $P<0 \cdot 02$, respectively). $M$. lucifugus and $M$. thysanodes showed no significant intraspecific changes in water index, although final values were lower than initial values. The water index of $M$. yumanensis decreased significantly during the study period $(P<0.001)$. Water indices showed a general tendency to complement the increases in fat indices. 


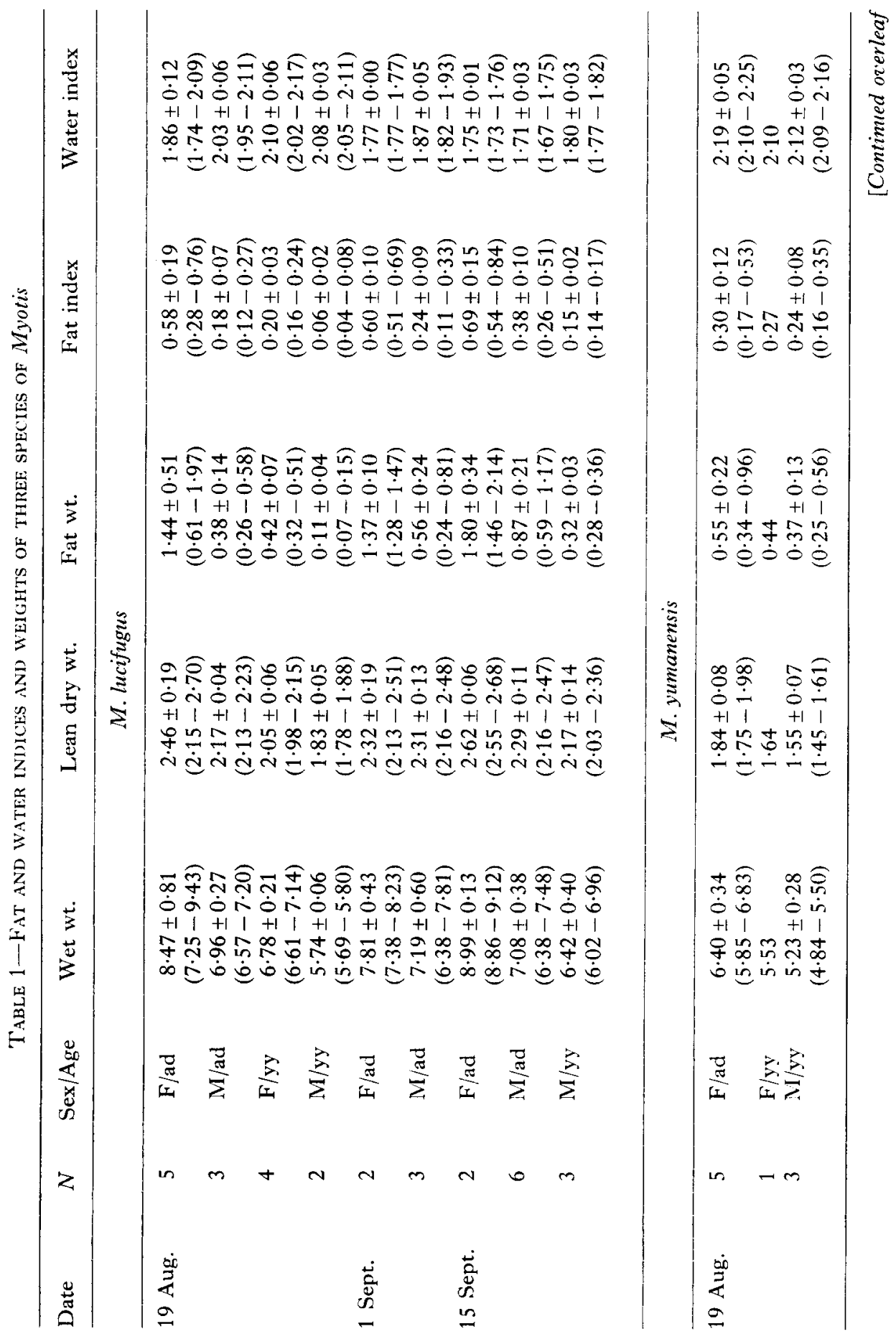


William G. Ewing, Eugene H. Studier and Michael J. O'Farrell.

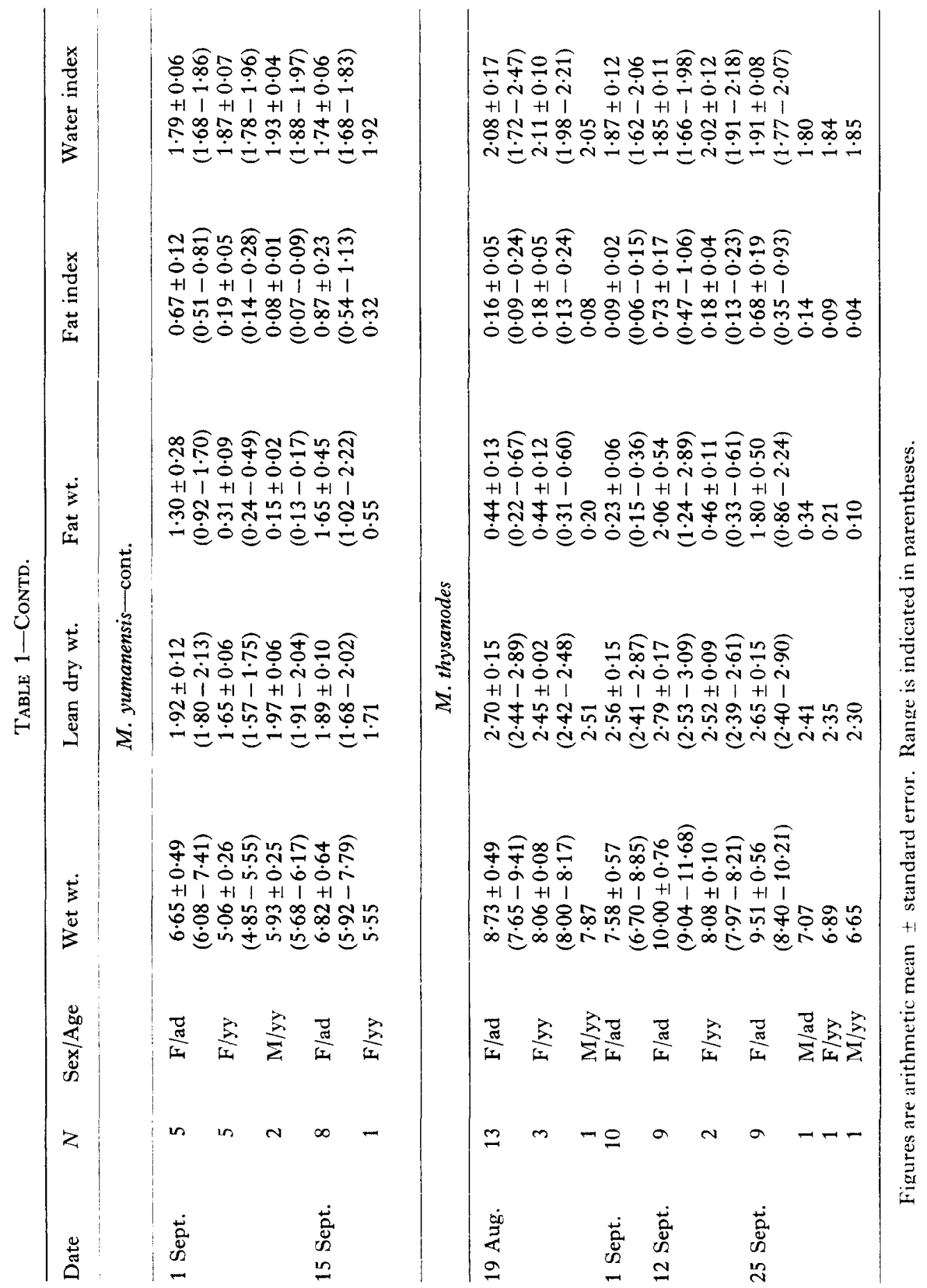


Fat-free adults showed no significant interspecific differences in nonfat organic, ash, or water content on corresponding days (Table 2). M. lucifugus occultus and $M$. thysanodes showed no significant intraspecific differences in these parameters during the study period, while $M$. yumanensis showed significantly increased nonfat organic material and percent water $(P<0.001$ and $P<0.01$, respectively).

Mean caloric content of $M$. thysanodes fat was $9 \cdot 418 \pm 0 \cdot 016$ (S.E. $\cdot{ }_{\cdot}$ ) kcal/g. This value is quite similar to that reported by Baker et al., (1969) for $N$. humeralis.

Table 2-Percentage gross body composition of fat-free adult $M y o t i s$

\begin{tabular}{|c|c|c|c|c|}
\hline Date & $N$ & $\begin{array}{l}\text { Non-fat } \\
\text { Organic }\end{array}$ & Ash & Water \\
\hline \multicolumn{5}{|c|}{ M. lucifugus } \\
\hline 19 Aug. & 8 & $\begin{array}{c}29 \cdot 0 \pm 1 \cdot 4 \\
(27 \cdot 2-31 \cdot 3)\end{array}$ & $\begin{array}{c}4.9 \pm 0.2 \\
(4 \cdot 6-5 \cdot 4)\end{array}$ & $\begin{array}{c}65 \cdot 7 \pm 1 \cdot 5 \\
(63 \cdot 5-67 \cdot 8)\end{array}$ \\
\hline 1 Sept. & 6 & $\begin{array}{c}29.9 \pm 0.7 \\
(29.1-30 \cdot 7)\end{array}$ & $\begin{array}{c}5 \cdot 4 \pm 0.5 \\
(4 \cdot 4-5 \cdot 9)\end{array}$ & $\begin{array}{c}64 \cdot 4 \pm 0 \cdot 8 \\
(63 \cdot 5-66 \cdot 0)\end{array}$ \\
\hline 15 Sept. & 8 & $\begin{array}{c}31 \cdot 3 \pm 0 \cdot 5 \\
(30 \cdot 4-31 \cdot 4)\end{array}$ & $\begin{array}{c}5 \cdot 6 \pm 0 \cdot 4 \\
(5 \cdot 2-6 \cdot 5)\end{array}$ & $\begin{array}{c}63 \cdot 1 \pm 0 \cdot 4 \\
(62 \cdot 5-63 \cdot 8)\end{array}$ \\
\hline \multicolumn{5}{|c|}{ M. yumanensis } \\
\hline 19 Aug. & 5 & $\begin{array}{c}26.5 \pm 0.5 \\
(26.1-27.4)\end{array}$ & $\begin{array}{c}4 \cdot 6 \pm 0 \cdot 2 \\
(4 \cdot 3-4 \cdot 9)\end{array}$ & $\begin{array}{c}68 \cdot 6 \pm 0 \cdot 4 \\
(67 \cdot 7-69 \cdot 1)\end{array}$ \\
\hline 1 Sept. & 5 & $\begin{array}{c}31 \cdot 2 \pm 0.5 \\
(30.5-32 \cdot 1)\end{array}$ & $\begin{array}{c}4 \cdot 8 \pm 0 \cdot 3 \\
(4 \cdot 4-5 \cdot 3)\end{array}$ & $\begin{array}{c}64 \cdot 1 \pm 0 \cdot 5 \\
(62 \cdot 7-65 \cdot 0)\end{array}$ \\
\hline 15 Sept. & 8 & $\begin{array}{c}31 \cdot 5 \pm 0 \cdot 7 \\
(30 \cdot 0-32 \cdot 3)\end{array}$ & $\begin{array}{c}5 \cdot 0 \pm 0 \cdot 2 \\
(4 \cdot 7-5 \cdot 4)\end{array}$ & $\begin{array}{c}63 \cdot 7 \pm 1 \cdot 5 \\
(62 \cdot 6-67 \cdot 3)\end{array}$ \\
\hline \multicolumn{5}{|c|}{ M. thysanodes } \\
\hline 19 Aug. & 10 & $\begin{array}{c}27 \cdot 6 \pm 1 \cdot 5 \\
(24 \cdot 4-31 \cdot 0)\end{array}$ & $\begin{array}{c}4 \cdot 9 \pm 0 \cdot 5 \\
(4 \cdot 2-5 \cdot 5)\end{array}$ & $\begin{array}{c}67 \cdot 4 \pm 1 \cdot 8 \\
(63 \cdot 2-71 \cdot 1)\end{array}$ \\
\hline 1 Sept & 10 & $\begin{array}{c}29 \cdot 3 \pm 1 \cdot 5 \\
(27 \cdot 3-32 \cdot 0)\end{array}$ & $\begin{array}{c}5 \cdot 5 \pm 0 \cdot 3 \\
(4 \cdot 8-6 \cdot 2)\end{array}$ & $\begin{array}{c}65 \cdot 1 \pm 1 \cdot 5 \\
(61 \cdot 7-71 \cdot 1)\end{array}$ \\
\hline 12 Sept. & 9 & $\begin{array}{c}30 \cdot 1 \pm 1 \cdot 3 \\
(28 \cdot 7-32 \cdot 6)\end{array}$ & $\begin{array}{c}5 \cdot 3 \pm 0 \cdot 1 \\
(5 \cdot 0-5 \cdot 4)\end{array}$ & $\begin{array}{c}64 \cdot 8 \pm 1 \cdot 4 \\
(62 \cdot 3-66 \cdot 4)\end{array}$ \\
\hline 25 Sept. & 9 & $\begin{array}{c}28 \cdot 8 \pm 0 \cdot 9 \\
(27 \cdot 1-30 \cdot 5)\end{array}$ & $\begin{array}{c}5 \cdot 5 \pm 0 \cdot 2 \\
(5 \cdot 1-5 \cdot 8)\end{array}$ & $\begin{array}{c}65 \cdot 6 \pm 1 \cdot 0 \\
(63 \cdot 8-67 \cdot 4)\end{array}$ \\
\hline
\end{tabular}

See Table 1 for explanation of figures.

Results of the fatty acid and lipid phosphorous analysis are presented in Table 3. Data for brown fat analysis of M. l. lucifugus (Wells et al., 1965) are presented for comparison. The most plentiful fatty acid in all cases was oleic acid $\left(\mathrm{C}_{18: 1}\right)$, followed in varying order by acids 16:0,16:1, and 18:2.

\section{General aspects of fat deposition}

\section{DISCUSSION}

Two generalizations are evident from this study that apply to each of the species examined: (1) adults deposit more fat than young of the year, and (2) females 
William G. Ewing, Eugene H. Studier and Michael J. O'Farkell

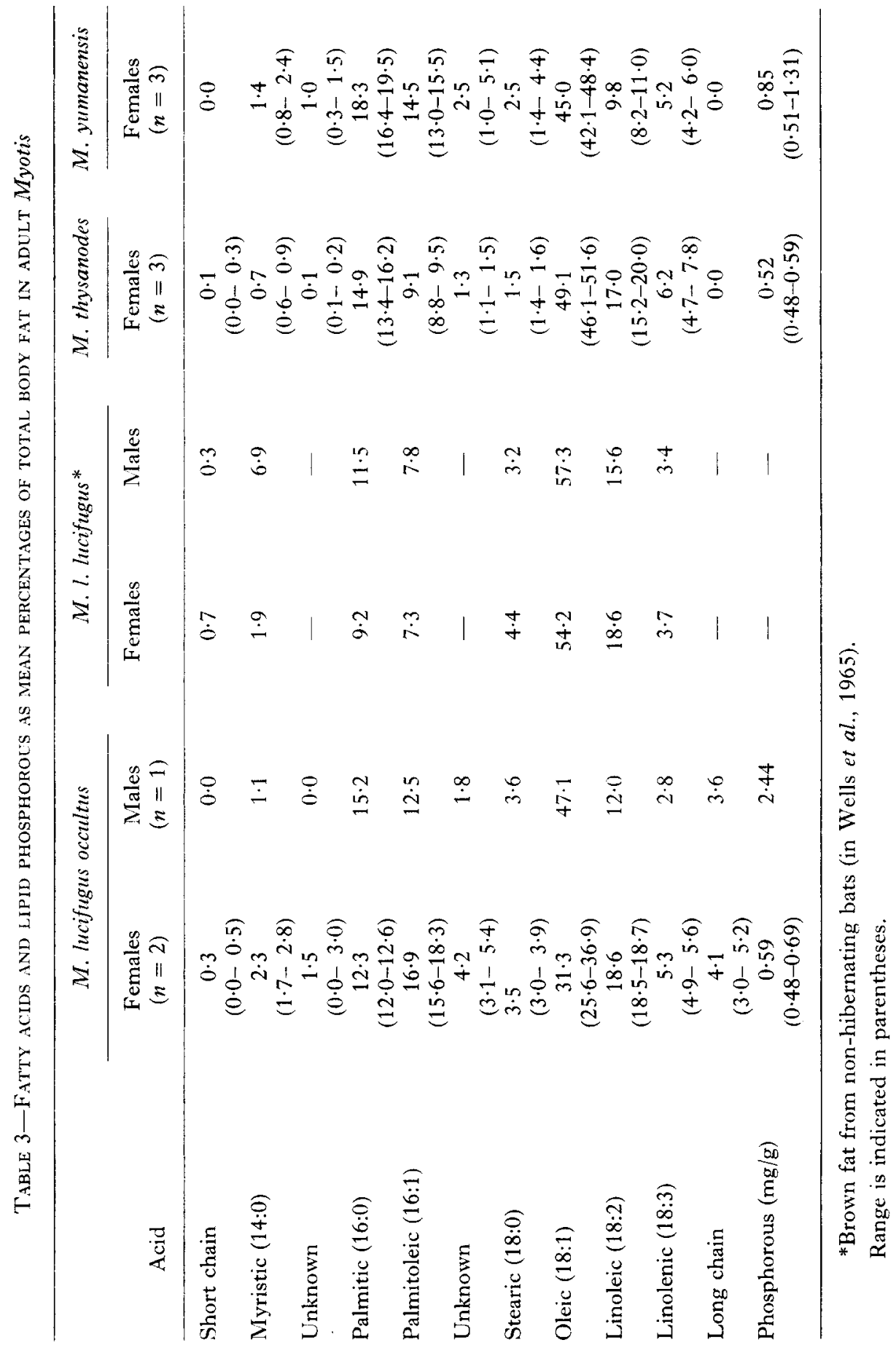


deposit more fat than males of the same age group. Similar autumn weight groupings with respect to age and sex have been reported for $M$. l. lucifugus (Davis $\&$ Hitchcock, 1965), M. velifer (Tinkle \& Patterson, 1965), and Pipistrellus subflavus (W. H. Davis, 1966). These differences may reflect a trend for survival value. Adult female $M$. l. lucifugus in New England deposit large quantities of fat in the fall, while juveniles remain comparatively lean. Furthermore, while older bats are entering hibernation, juveniles remain active as long as there is an opportunity to feed (Davis \& Hitchcock, 1965). Similarly, adult female $M$. lucifugus occultus leave the Montezuma roost earlier in the fall than do juveniles or male adults of the same species (personal observation). The differences in fat content between male and female adult $M$. lucifugus occultus suggest that females have a better chance of surviving the winter than males. It should be noted that fat content was determined immediately prior to leaving the summer roost, and males and juveniles may undergo fat deposition from the time they leave the summer roost until the onset of hibernation.

The fat index is high $(2 \cdot 0-3 \cdot 0)$ in birds that fly continuously without foraging during their migration (Odum, 1965), while the fat indices of the Myotis in this study are relatively low. Baker et al., (1968), reported autumn fat indices of 1.51.7 for $N$. humeralis, and Weber \& Findley (1970) reported fat indices of 1.6-1.8 for E. fuscus in September. Studier et al., (1970) have shown that M. lucifugus occultus may lose roughly 10 per cent of their body weight within a few hours of their return to the roost at dawn. Thus, our fat indices as well as those reported for other bats may indicate a smaller fat store than actually exists.

\section{Energetics}

Fat indices and rates of fat deposition differ greatly in adult females of the three species studied. Fat deposition in $M$. lucifugus occultus appears to be nearly completed by mid-August. This observation correlates well with metabolic studies of this animal (O'Farrell \& Studier, 1970) and of M. l. lucifugus (Stones \& Wiebers, 1967) which have shown that this species exhibits a non-homeothermic relationship of metabolic rate to ambient temperature at this time of year. Metabolic studies of $M$. yumanensis from mid-August to mid-September have shown that this relationship is non-homeothermic for some individuals and partially homeothermic for others (O'Farrell \& Studier, 1970). This correlates with a significant increase in fat index during the same time span. In M. thysanodes, however, the relationship of metabolic rate to ambient temperature has been shown to undergo a clear transition from homeothermic to non-homeothermic during September (O’Farrell \& Studier, 1970), during which time this species deposits a highly significant amount of fat.

O'Farrell \& Studier (1970) give metabolic rates (dry air, $20 \cdot 5^{\circ} \mathrm{C}$ ) for $M$. thysanodes of $6.929 \mathrm{~cm}^{3} \mathrm{O}_{2} / \mathrm{g}$ per $\mathrm{hr}$ for homeothermic bats and $0.588 \mathrm{~cm}^{3} \mathrm{O}_{2} / \mathrm{g}$ per $\mathrm{hr}$ for non-homeothermic bats, a decrease of $6.341 \mathrm{~cm}^{3} \mathrm{O}_{2} / \mathrm{g}$ per hr. Assuming a mean body weight of $7.64 \mathrm{~g}$ and a daily rest period of $12 \mathrm{hr}$ (a conservative estimate), the change in oxygen consumption is $581 \mathrm{~cm}^{3} /$ day. Using the energy equivalent of 
oxygen, $4.825 \mathrm{kcal} / 1$, we calculate that the bat conserves $2.81 \mathrm{kcal} /$ day as it becomes non-homeothermic. During the interval of maximum fat deposition, fat is deposited at a rate of $0.17 \mathrm{~g} /$ day. At $9.4 \mathrm{kcal} / \mathrm{g}$ fat, the bats require $1.60 \mathrm{kcal} /$ day for fat deposition. It therefore seems justified to state that the energy necessary for fat deposition comes at least in part from the energy conserved by the development of non-homeothermy. This supports Krzanowski's (1961) postulation that in autumn, energy for fat deposition in bats comes from the development of hypothermia during the day.

Gifford \& Odum (1965) discuss two hypotheses to explain how birds maintain a positive energy balance during prolonged migratory flights. The first hypothesis, proposed by Wachs (1926), is that birds experience a general reduction in basal metabolism or an increase in assimilation efficiency, and the second is that birds become hyperphagic and deposit fat prior to migration. The latter hypothesis has been shown to apply for many species of birds (Odum, 1960; Gifford \& Odum, 1965), while the former applies to the three species of Myotis in this study and may apply to many bats that migrate or hibernate. Furthermore, $M$. lucifugus and $M$. thysanodes have been shown not to become hyperphagic during their period of fat deposition (Studier, unpublished data).

Part of the difficulty in interpreting the significance of fat deposition in these Myotis is that the winter behaviour of the bats of the Montezuma colony is unknown. We presume that they spend the major part of the winter in hibernation as do other Myotis (Davis \& Hitchcock, 1965; Tinkle \& Patterson, 1965), although hibernacula for the species studied are unknown. The maximum range that a bat can fly with a known level of stored fat can be calculated by the following formula:

$$
\text { Maximum range in miles }=\frac{(\text { wt. fat })(\mathrm{kcal} / \mathrm{g} \mathrm{fat})(\text { flight speed mph) }(1000)}{\left(M R_{\mathrm{r}}\right)(12 \cdot 8)(\mathrm{wt} . \mathrm{bat})\left(4.8 \mathrm{kcal} / 1 . \mathrm{O}_{2}\right)}
$$

The term $M R_{\mathrm{r}}$ is the metabolic rate $\left(\mathrm{cm}^{3} \mathrm{O}_{2} / \mathrm{g}\right.$ per $\left.\mathrm{hr}\right)$ of a resting homeothermic bat at thermoneutrality. Metabolic rate in flight is estimated by multiplying $M R_{\mathrm{r}}$ by $12 \cdot 8$, a factor reported by Tucker (1968) for birds. This factor has been used for bats as well (Carpenter, 1969). For $M$. lucifigus, $M R_{\mathrm{r}}$ can be estimated at $1.7 \mathrm{~cm}^{3} \mathrm{O}_{2} / \mathrm{g}$ per hr (Stones \& Wiebers, 1967), flight speed is considered $20 \mathrm{mph}$ (R. Davis, 1966), weight of the bat is $8.9 \mathrm{~g}$, weight of the fat stored is $1.8 \mathrm{~g}$ (Table 1 ), and caloric content of the fat is $9.4 \mathrm{kcal} / \mathrm{g}$. Hence, the calculated maximum range from the summer roost is 364 miles. For $M$. yumanensis, $M R_{\mathrm{r}}$ is $1.91 \mathrm{~cm}^{3}$ $\mathrm{O}_{2} / \mathrm{g}$ per hr (O’ Farrell \& Studier, 1970), flight speed is $8.9 \mathrm{mph}$ (Hayward \& Davis, 1964), bat weight is $6.8 \mathrm{~g}$, and fat weight is $1.6 \mathrm{~g}$. The calculated maximum range is 168 miles. For $M$. thysanodes $M R_{\mathrm{r}}$ is $1.74 \mathrm{~cm}^{3} \mathrm{O}_{2} / \mathrm{g}$ per hr (O'Farrell \& Studier, 1970 ), flight speed is $9.8 \mathrm{mph}$ (Hayward \& Davis, 1964), bat weight is $10.0 \mathrm{~g}$, and fat weight is $2.0 \mathrm{~g}$. The calculated maximum range is 172 miles. The most questionable factor in this calculation is the factor by which $M R_{\mathrm{r}}$ is increased in flight. For example, if this factor were $16 \cdot 0$, the maximum range of $M$. thysanodes would be 137 miles. Studier \& Howell (1969) estimated the metabolic rate of $E$. fuscus in flight to be between 25.7 and $38.5 \mathrm{~cm}^{3} \mathrm{O}_{2} / \mathrm{g}$ per $\mathrm{hr}$, which is a factor of 
$19 \cdot 8$ to $29 \cdot 6$ above $M R_{\mathrm{r}}\left(1 \cdot 3 \mathrm{~cm}^{3} \mathrm{O}_{2} / \mathrm{g}\right.$ per hr $)$ reported for this species by Herreid \& Schmidt-Nielsen (1966). It seems, therefore, that our calculated flight ranges may be considerable overestimates. Furthermore, no correction can be included for the possibility that these bats may forage while flying to the winter roost.

An analagous formula can be designed to calculate the maximum number of days that a bat could spend in hibernation with a known amount of stored fat:

$$
\text { Maximum days in hibernation }=\frac{(\text { wt. fat })(\mathrm{kcal} / \mathrm{g} \mathrm{fat})(1000)}{\left(M R_{\mathrm{h}}\right)(\text { wt. bat })(24 \mathrm{hr} / \text { day })\left(4 \cdot 8 \mathrm{kcal} / 1 . \mathrm{O}_{2}\right)}
$$

Estimating the metabolic rate in hibernation, $M R_{\mathrm{h}}$, at $0 \cdot 1 \mathrm{~cm}^{3} \mathrm{O}_{2} / \mathrm{g}$ per hr (Hock, 1951), we calculate maximum days in hibernation as follows: $M$. lucifugus occultus, 165 days; $M$. yumanensis, 192 days; $M$. thysanodes, 163 days. The most critical variable in this calculation is $M R_{\mathrm{h}}$. For example, if $M R_{\mathrm{h}}$ for $M$. thysanodes were $0.15 \mathrm{~cm}^{3} \mathrm{O}_{2} / \mathrm{g}$ per $\mathrm{hr}$, the maximum time in hibernation would be 109 days. Furthermore, this calculation assumes that hibernating bats remain totally inactive $24 \mathrm{hr}$ per day. Any periodic arousal would greatly decrease the energy available for hibernation.

We can speculate from these two calculations that these Myotis probably migrate for not more than 100-200 miles to their hibernacula and feed for a while prior to hibernation to replenish expended fat stores. It seems most likely that these hibernacula would be located to the south and east of the Montezuma colony where the elevation is lower and the cold season much shorter.

\section{Lipid analysis}

Analysis of the fatty acids of body fat showed a predominance of unsaturated fatty acids (72-81 per cent) with oleic acid being most common. This is consistent with the findings of Wells et al. (1965) for brown fat of non-hibernating $M . l$. lucifugus and Paulsrud and Dryer (1968) for brown fat of $E$. fuscus entering hibernation. A high level of unsaturated fatty acids is a common occurrence in animals preparing for hibernation and appears to be related to a lowering of the environmental temperature (Fawcett \& Lyman, 1954). A high content of palmitoleic acid occurred in each species in our study. This is unusual for animal body fat (Jenness, personal communication), although it has been reported for bat body fat (Wells $e t$ al., 1965; Paulsrud \& Dryer, 1968).

\section{Gross body composition}

Migratory birds studied by Odum et al. (1964), Rogers \& Odum (1964) and Hicks (1967) have been shown to undergo large changes in gross body weight without appreciable change in gross body composition during seasonal fat deposition and depletion. This phenomenon is attributable to a filling of pre-existing adipose cells rather than a building of new adipose tissue. Such also is the case with $M$. thysanodes, which we have shown to deposit a relatively large amount of fat in a short time without significant change in gross body composition. M. yumanensis, however, deposited a significant amount of fat during the entire study period and 
simultaneously increased nonfat organic and water content. Both gradual fat deposition and increase in gross body composition may be interpreted as a building of new adipose tissue. The constancy of gross body composition in M. lucifugus occultus is relatively meaningless because this species underwent no significant change in fat content.

Acknowledgements - We wish to thank Dr. Neil S. Weber and Dr. James S. Findley for allowing us to read their manuscript before its publication and Dr. Robert Jenness and Dr. R. L. Glass for their generous cooperation in carrying out our fatty acid analyses.

\section{REFERENCES}

Baker W. W., Marshall S. G. \& Baker V. B. (1968) Autumn fat deposition in the erening bat (Nycticieus humeralis). F. Mammal. 49, 314-317.

CaRPenter R. E. (1969) Structure and function of the kidney and the water balance of desert bats. Physiol. Zoöl. 42, 288-302.

Christopherson S. W. \& Glass R. L. (1969) Preparation of milk fat methyl esters by alcoholysis in an essentially non-alcoholic solution. F. Dairy Sci. 52, 1289-1290.

Davis R. (1966) Homing performance and homing ability in bats. Ecol. Monogr. 36, 201-237.

Davis W. H. (1966) Population dynamics of the bat Pipistrellus subflavis. F. Mammal. 47, $383-396$.

Davis W. H. \& Hitchcock H. B. (1965) Biology and migration of the bat, Myotis lucifugus, in New England. F. Mammal. 46, 296-313.

FawcetT D. \& Lyman C. P. (1954) The effect of low environmental temperature on the composition of depot fat in relation to hibernation. F. Physiol., Lond. 126, 235.

Findley J. S. \& Jones C. (1967) Taxonomic relationships of the species Myotis fortidens, M. lucifugus, and M. occultus. F. Mammal. 48, 429-444.

Gifford C. E. \& Odum E. P. (1965) Bioenergetics of lipid deposition in the bobolink, a trans-equatorial migrant. Condor 67, 383-403.

Hayward B. J. \& Davis R. (1964) Flight speeds in western bats. F. Mammal. 45, 236-242.

HerReid C. F. II (1963) Survival of a migratory bat at different temperatures. F. Mammal. 44, 431-433.

Herreid C. F., II \& Schmidt-Neilsen K. (1966) Oxygen consumption, temperature and water loss in bats from different environments. Am.F. Physiol. 211, 1108-1112.

Hicks D. L. (1967) Adipose tissue composition and cell size in fall migratory thrushes (Turdidae). Condor 69, 387-399.

Hock R. J. (1951) The metabolic rates and body temperatures of bats. Biol. Bull. mar. biol. Lab., Woods Hole 101, 289-299.

King J. R. \& FARNer D. S. (1965) Studies on fat deposition in migratory birds. Ann. N. Y. Acad. Sci. 131, 422-440.

Krzanowski A. (1961) Weight dynamics of bats wintering in the cave at Pulway (Poland). Acta Theriologica 4, 249-264. (In Weber \& Findley, 1970).

Odum E. P. (1960) Premigratory hyperphagia in birds. Am. F. Clin. Nutr. 8, 621-629.

Odum E. P., Rogers D. T. \& Hicks D. L. (1964) Homeostasis of the nonfat components of migrating birds. Science 143, 1037-1039.

ODum E. P. (1965) Adipose tissue in migratory birds. Handbook of Physiology, Section 5, pp. 37-43; Adipose tissue. Am. Physiol Soc, Washington, D.C.

O'FarRell M. J. \& Studier E. H. (1970) Fall metabolism in relation to ambient temperatures in three species of Myotis. Comp. Biochem. Physiol. (In press).

Paulsrud J. R. \& Dryer R. L. (1968) Circum-annual changes in triglyceride fatty acids of bat brown adipose tissue. Lipids 3, 340-345. 
Rogers D. T. \& Odum E. P. (1964) The effect of age, sex, and level of lipid deposition on major body components in some Wood Warblers. Auk 81, 505-513.

Stones R. C. \& Wiebers J. E. (1967) Temperature regulation in the little brown bat, Myotis lucifugus. In Mammalian Hibernation III (Edited by Fisher K. C., Dawe A. R., Lyman C. P., Schonbaum E. \& South F. E., Jr.), pp. 97-109. Oliver \& Boyd and American Elsevier, New York.

Studier E. H. \& Howell D. J. (1969) Heart rate of female big brown bats in flight. $\mathcal{F}$. Mammal. 50, 842-845.

Studier E. H., Procter J. W. \& Howell D. J. (1970) Diurnal body weight loss and tolerance of weight loss in five species of Myotis. 7. Mammal. 51, 302-309.

Tinkle D. W. \& Patterson I. G. (1965) A study of hibernating populations of Myotis zelifer in northwest Texas. $\mathcal{F}$. Mammal. 46, 612-633.

TuckeR V. A. (1968) Respiratory exchange and evaporative water loss in the flying budgerigar. Y.exp. Biol. 48, 67-87.

Wachs H. (1926) Die Wanderungen der Vögel. Ergeb. Biol. 1, 479-637. (In Gifford \& Odum, 1965).

Weber N. S. \& Findley J. S. (1970) Warm season changes in fat content of Eptesicus fuscus. F. Mammal. 51, 160-162.

Wells H. J., Makita M., Wells W. W. \& Krutzsch P. H. (1965) A comparison of the lipid composition of brown adipose tissue from male and female bats (Myotis lucifugus) during hibernating and non-hibernating seasons. Biochim. biophys. Acta 98, 269-277.

Key Word Index-Bats, body composition; Chiroptera; fat composition; fat deposition; Myotis; Vespertilionidae. 